Jorgensen, J. G., L. R. Dinan, and M. Bomberger Brown. 2016. Flight initiation distances of nesting Piping Plovers (Charadrius melodus) in response to human disturbance. Avian Conservation and Ecology 11(1):5. http://dx.doi.org/10.5751/ACE-00826-110105

Copyright (C) 2016 by the author(s). Published here under license by the Resilience Alliance.

Research Paper

\title{
Flight initiation distances of nesting Piping Plovers (Charadrius melodus) in response to human disturbance
}

\author{
Joel G. Jorgensen ${ }^{1}$, Lauren R. Dinan ${ }^{1}$ and Mary Bomberger Brown ${ }^{2}$ \\ ${ }^{1}$ Nongame Bird Program, Nebraska Game and Parks Commission, ${ }^{2}$ School of Natural Resources, University of Nebraska, Lincoln, \\ Nebraska
}

\begin{abstract}
Birds frequently interact with people when they occur in coupled human-ecological or anthropogenic environments, which makes the protection of legally protected species a challenge. Flight initiation distances (FIDs) are often used to inform development of appropriate buffer distances required for human exclusion zones used to protect birds nesting in anthropogenic landscapes. Piping Plovers (Charadrius melodus) are protected by the Endangered Species Act in the United States and often nest in areas used by humans. Studies evaluating Piping Plover FIDs are limited and implementation of exclusion zones has been inconsistent across the species' range. We measured Piping Plover response and FIDs to naturally occurring stimuli on public beaches at Lake McConaughy, Nebraska, USA. Piping Plover FIDs differed most by stimulus class (vehicle, human, dog, human with dog), Julian day, and hour of day. Piping Plover FIDs were greatest for dog and human with dog compared to humans and vehicles. For all types of stimuli, Piping Plover FIDs decreased over time during the nesting season and increased slightly during each day. In the majority of instances in which Piping Plovers left their nests, return times to the nest were relatively short (less than three minutes). These results suggest Piping Plovers become habituated to the presence of human-related stimuli over the course of a nesting season, but other explanations such as parental investment and risk allocation cannot be excluded. Additional research and improved guidance regarding the implementation of exclusion zones is needed so managers can implement effective protection programs in anthropogenic landscapes.
\end{abstract}

\section{Distances de fuite de Pluviers siffleurs (Charadrius melodus) nicheurs en réaction au dérangement humain}

RÉSUMÉ. Souvent, les oiseaux interagissent avec les humains lorsqu'ils fréquentent des environnements mixtes anthropiques-naturels ou anthropiques, rendant difficile la protection d'espèces protégées légalement. On utilise couramment la distance de fuite (DF) afin de déterminer une distance sécuritaire appropriée pour des zones d'exclusion humaine nécessaires à la protection d'oiseaux qui nichent dans des paysages anthropiques. Les Pluviers siffleurs (Charadrius melodus) sont protégés en vertu de la Loi sur les espèces en péril (Endangered Species Act) aux États-Unis et nichent régulièrement dans des endroits aussi utilisés par les humains. Les recherches visant à évaluer les DF des Pluviers siffleurs sont peu nombreuses et la mise en place de zones d'exclusion humaine a été inégale dans l'ensemble de l'aire de répartition de cette espèce. Nous avons mesuré la réaction des pluviers et les DF en présence de stimuli naturels sur les plages publiques au lac McConaughy, au Nebraska, États-Unis. Les DF des pluviers ont surtout varié selon le type de stimuli (véhicule, humain, chien, humain avec chien), le jour julien et l'heure du jour. Les DF des pluviers étaient le plus élevées en présence de chiens et d'humains avec des chiens, comparativement à la présence d'humains et de véhicules. Pour tous les types de stimuli, les DF diminuaient au fil de la saison de nidification et augmentaient légèrement en fonction de l'heure du jour. Dans la majorité des cas où les pluviers ont quitté leur nid, le temps qu'ils ont mis à y retourner était plutôt court (moins de trois minutes). Nos résultats indiquent que les Pluviers siffleurs s'habituent à la présence de stimuli liés aux humains au cours d'une saison de nidification, mais d'autres explications, comme l'investissement parental et la prise en compte du risque, ne peuvent pas être écartées. Davantage de recherches et de meilleures directives en ce qui concerne la mise en place de zones d'exclusion humaine sont nécessaires pour que les gestionnaires soient bien outillés au moment de la mise en oeuvre des programmes de protection efficaces dans les paysages anthropiques.

Key Words: Charadrius melodus; flight initiation distance; human disturbance; Piping Plover; recreation

\section{INTRODUCTION}

Birds, including legally protected threatened and endangered species, frequently interact with people when they occur in coupled human-ecological or anthropogenic environments (Crooks et al. 2004). The presence of people in close proximity to birds, particularly during sensitive periods such as nesting or brood rearing, can result in negative consequences to the birds (Carney and Sydeman 1999). Human activity can displace birds from key nesting, foraging, or brooding habitats (Stillman and Goss-Custard 2002), destroy nests, or kill adults and young (Boyle and Samson 1985), or disrupt or alter important behaviors (Weston and Elgar 2007). Although humans have the ability to intentionally or unintentionally harm birds, they also have the capacity to protect them from harm. This can be achieved in a variety of ways, but often it is done by creating exclusion zones around nesting areas or other important habitat. Exclusion zones 
provide a buffer area where human access is restricted (Rodgers and Smith 1995). Unless compromised by noncompliance, exclusion zones are effective if they are large enough to separate birds from human activity and allow the birds to carry out their normal behaviors and complete important life cycle events, e.g., nesting, without interference (Burger et al. 2010).

Birds and other animals usually flee approaching predators, including humans. The distance at which this occurs is referred to as the flight initiation distance (FID; Ydenberg and Dill 1986). The response to a threat, which FIDs estimate, may not always result in negative consequences to an individual (Gill et al. 2001) if they occur infrequently; the cumulative effect of repeated or prolonged disturbances, however, may have negative consequences. Studies have shown birds' responses and FIDs are species, and individual, specific (Blumstein et al. 2003) and are influenced by site (Blumstein et al. 2003), direction of approach (FernándezJuricic et al. 2005, Eason et al. 2006), time of day (Burger and Gochfield 1991), group size (Liao et al. 2005), number of people in close proximity (Burger and Gochfield 1991), time of their nesting cycle (Burger et al. 2010), and whether a human is accompanied by a dog (Lord et al. 2001). FIDs vary because individuals must assess the trade-offs between (1) the costs of fleeing, (2) the perceived risk of the threat, and (3) possible fitness consequences (Ydenburg and Dill 1986, Ikuta and Blumstein 2003, Yasué and Dearden 2006). The variability in FIDs and the array of variables that influence FIDs make identifying a single buffer size for human exclusion zones challenging.

Some species appear to become habituated to human activity and are less likely to respond to humans with repeated exposure (Burger and Gochfield 1983, Nisbet 2000, Baudains and Lloyd 2007). Risk allocation has been proposed as an alternative explanation to habituation in settings where the likelihood of a response decreases with increasing frequency of threat (Lima and Bednekoff 1999, Rodriguez-Prieto et al. 2009). During the nesting season individuals experiencing temporal or seasonal variation in the risk of predation must balance their response to the level of risk and their level of investment in nesting experienced at the time of the threat (parental investment, sensu Trivers 1974, Lima and Bednekoff 1999). If birds' likelihood of response does not decrease, they may flee so frequently in response to repeated threats they would be unable to meet their biological needs, e.g., foraging, nest incubation, brood rearing (Rodriguez-Prieto et al. 2009). For adult birds incubating eggs or attending chicks, responding to threats is affected by the trade-off between their own survival and their chicks' survival (adult survival versus reproductive success; Clark and Ydenberg 1990, de Jong et al. 2013).

Several shorebird species of high conservation concern are intensively managed because they nest and rear their young on sandy beaches that are also heavily used by humans for recreation (Flemming et al. 1988, Stillman and Goss-Custard 2002, Lafferty et al. 2006, Weston and Elgar 2007). The Piping Plover (Charadrius melodus) is one of these species. Management and protection is required across their breeding range (Melvin et al. 1994, USFWS 1994) because of their status under the United States Endangered Species Act (ESA; 7 U.S.C. $\S 136,16$ U.S.C. $\S 1531$ et seq.). Historically, they nested and reared their chicks on expanses of sand adjacent to water with little human interference. Presently, they are increasingly found nesting in habitats also used by humans for recreation (Flemming et al. 1988), aggregate mining, and residential housing (Brown et al. 2010). The presence of humans, their vehicles, and pets, i.e., dogs, in plover nesting areas can lead to bird-human conflicts with significant consequences to the nesting birds, including (1) the physical destruction of nests and chicks and (2) changes in behavior by plovers to avoid these threats that may indirectly reduce nest or chick survival (Flemming et al. 1988, Burger 1991, 1994, Deblinger et al. 1992, Melvin et al. 1994).

In addition to the negative biological consequences to the birds, human activity in nesting areas may have negative legal consequences for the people involved. Under the ESA, harassment is defined as human disturbance that significantly disrupts normal behavior patterns and creates the possibility of injury to an ESA-listed species. Harassment caused by human activities that result in negative impacts to Piping Plovers may represent instances of "take," which is prohibited by the ESA and perpetrators can be prosecuted (USFWS 1988, 1996, 2003). Under Section 7 of the ESA, federal agencies are required to take steps to protect and avoid take of species listed as threatened or endangered when their actions, such as issuing a permit or funding of a project, may negatively impact the species (USFWS 1994, 2003). Collectively, these provisions of the ESA require humans to manage and protect Piping Plovers and their nesting areas. Human exclusion zones provide a buffer from disturbance and are part of the standard repertoire of methods used to protect Piping Plovers.

The implementation of Piping Plover exclusion zones has not been consistent across the species' range. This inconsistency is due to several factors, including (1) limited data available on Piping Plover FIDs in response to human disturbance, (2) legal vagaries in the ESA and lack of guidance provided by regulatory agencies, and (3) lack of clarity regarding the objectives of human exclusion zones. Guidance regarding exclusions zones provided by the federal recovery plans are limited (USFWS 1988, 1996, 2003). It is unclear whether the purpose of exclusion zones is to prevent (1) all instances where humans elicit a behavioral response by nesting Piping Plovers or (2) any disturbance that results in some measureable adverse effect, such as nest abandonment or reduced survival of eggs, chicks, or adults. One guidance document recommends $50 \mathrm{~m}$ diameter buffers be placed around nests, but states the size should be increased when $50 \mathrm{~m}$ is inadequate; the document does not specify how human exclusion zones should be evaluated to determine whether they are adequate or not (USFWS 1994). The $50 \mathrm{~m}$ buffer distance (USFWS 1994) was based on studies in which Piping Plover FIDs in response to human disturbance were quite variable, ranging from less than 5 $\mathrm{m}$ to $210 \mathrm{~m}$ (Flemming et al. 1990, Cross 1990, Loegering 1992, Hoopes 1993, Cross and Terwilliger 1993, all cited in USFWS 1994). In practice, the size and configuration of exclusion zones are left to the discretion of local managers whose experience with the species and best management practices may be lacking. Consequently, the buffer distances of exclusion zones are highly variable, with reported distances ranging from 16 to $800 \mathrm{~m}$ (USFWS 1994, 2003, Jorgensen and Brown 2015).

The variability in disturbance distance that elicits a flight response by Piping Plovers suggests a number of variables affect birds' responses to human activity. Previous studies only evaluated Piping Plover response to human pedestrians; they did not 
evaluate other sources of disturbance, e.g., dogs or vehicles, associated with humans. Other species of beach-nesting plovers are known to respond to different types of disturbance at different distances and frequencies (Lord et al. 2001, Weston and Elgar 2007). For example, New Zealand Dotterels' (Charadrius obscurus) FIDs were greater for a person leading a dog than to persons running or walking on the beach (Lord et al. 2001).

Even though human activity is intensely managed to protect Piping Plovers, relationships between human disturbance and variables affecting Piping Plover FIDs remain poorly understood. We evaluated Piping Plover response to natural stimuli capable of eliciting behavioral responses of adult birds incubating eggs in nests at Lake McConaughy, Keith County, Nebraska, USA. Our objectives in this study were to (1) identify response rates and FIDs of nesting Piping Plovers in response to different types of stimuli, (2) identify variables influencing Piping Plover FIDs, and (3) evaluate whether those stimuli and the birds' responses have the potential to negatively affect nesting success. We used natural stimuli occurring as part of normal human recreation to describe the stimulus environment and the amount of disturbance regularly experienced by nesting Piping Plovers. Our hypothesis was that Piping Plover response rates and response distances would be different for different types of natural stimuli and would change over the incubation period. Our prediction was that Piping Plovers would become less likely to flee from human-related stimuli and their response distances would decrease over the incubation period.

\section{METHODS}

\section{Study species}

Piping Plovers nest on sandy substrates, including midstream river sandbars, sand beaches, and other locations with sandy substrates along the Atlantic Coast, Great Lakes, and Great Plains of North America (Elliott-Smith and Haig 2004). They typically lay four eggs in shallow, cup-shaped nests in the sand, incubate the eggs for approximately four weeks, and attend to the precocial chicks for approximately four weeks; broods are reared in the general vicinity of the nest (Elliott-Smith and Haig 2004). Adult plovers and their nests and chicks may be present in nesting areas from mid-April through mid-August. They migrate to the Atlantic and Gulf coasts and Caribbean islands during the winter. Plovers will return to nest at the same location from year to year if suitable habitat is present (Elliott-Smith and Haig 2004). Piping Plovers are territorial and display aggression toward other Piping Plovers (Elliott-Smith and Haig 2004), particularly when breeding densities are high (Catlin 2009).

\section{Study area}

We studied Piping Plovers at Lake McConaughy, a 35-km long reservoir located near Ogallala, Keith County, Nebraska, USA (41 ${ }^{\circ} 14^{\prime} 09.6^{\prime \prime} \mathrm{N}, 101^{\circ} 44^{\prime} 27.0^{\prime \prime} \mathrm{W}$; Fig. 1) created by the construction of Kingsley Dam during the late 1930s and 1940s to impound the North Platte River for irrigation purposes. A hydroelectric generating plant was added to the dam in the mid-1980s. Lake McConaughy possesses areas of white sand beaches that support variable numbers of nesting plovers (low 10s to low 100s; maximum $=358$ in 2006; Elliott-Smith et al. 2009, 2015). Water elevation of the lake is variable within and between years depending on inflows and outflows. Consequently, the amount of exposed beach available to nesting birds is also variable within and between years. For example, during the summers of 2013 and 2014, the water elevation level in Lake McConaughy was at less than $75 \%$ of full capacity and declined as the season progressed, which created additional plover nesting habitat. During the summer of 2015, the water elevation level was at approximately $75 \%$ of full capacity in May, but rapidly increased to full capacity in early July, which eliminated nearly all extant nesting habitat (JGJ, MBB, personal observation).

Fig. 1. Piping Plover (Charadrius melodus) nesting areas at Lake McConaughy, Keith County, Nebraska, USA.

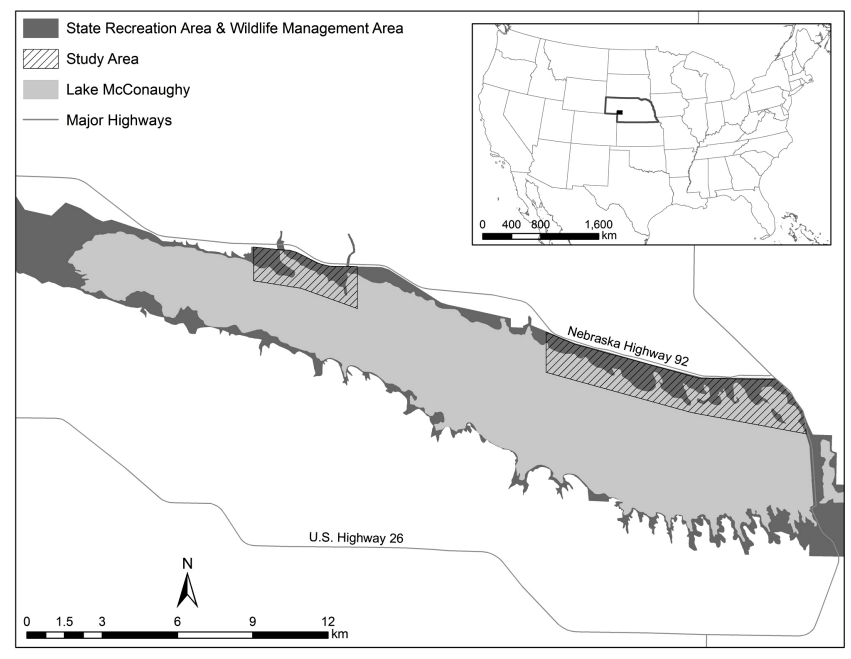

Lake McConaughy and the surrounding beaches are used intensively by people for recreation, primarily swimming, boating, fishing, and camping. Small communities, concessionaires, e.g., convenience stores and restaurants, and cattle ranching operations are located around the lake. Every year more than one million people visit Lake McConaughy, primarily during the summer months (Nebraska Game and Parks Commission, unpublished data). The period overlaps with the Piping Plover breeding season, which extends from mid-April through July (Peyton and Wilson 2013, 2014). The majority of recreationists visiting the lake are from the Front Range Urban Corridor (FRUC; Cheyenne, Wyoming to Denver and Colorado Springs, Colorado) or from the local area (Jorgensen and Brown 2015). The majority of plovers nest along the north shore of Lake McConaughy because extensive sand beaches are present only on this side of the lake. The majority of human (recreational) activities also occur on the north side of the lake because of the extensive sand beaches and access to recreation infrastructure, e.g., boat ramps, beach access points.

Lake McConaughy and the plovers that nest there exist in a complex regulatory and stakeholder environment. Kingsley Dam and Lake McConaughy are operated by Central Nebraska Public Power and Irrigation District (CNPPID) under the auspices of the Federal Energy Regulatory Commission (FERC license 1417). FERC license issuance is a federal action requiring ESA Section 7 consultation with the U.S. Fish and Wildlife Service (USFWS). The terms of the license require CNPPID to 
implement a comprehensive management plan for Piping Plovers nesting on beaches surrounding the lake to comply with the ESA (CNPPID 2002, see Jorgensen and Brown 2015 for additional details regarding the regulatory environment). As part of their management plan, CNPPID constructs two types of exclusion zones to protect nesting plovers. A small number of large zones, set off by orange plastic fencing and Keep Out signs, cover up to 16 ha of beach. Smaller zones, measuring approximately $16 \times 16$ $\mathrm{m}$ or $31 \times 31 \mathrm{~m}$ (the latter size used only in 2013), are placed around individual nests and include a $1 \mathrm{x} 1 \mathrm{~m}$ wire mesh exclosure and psychological fencing (twine with reflective tape) with Keep Out signs; the nest is located at the center of these smaller zones. Plover nests located inside the large zones are not protected by wire mesh exclosures. Lake McConaughy is leased to the Nebraska Game and Parks Commission, the agency that manages recreation.

\section{Spatial and temporal sampling}

We studied nesting Piping Plovers from mid-May to mid-July in 2013 and 2014. Behavioral observations were conducted in conjunction with studies focused on dog leash law compliance and recreationists' awareness of and attitudes toward Piping Plovers (Jorgensen and Brown 2014, 2015). We divided the study period into day types (weekends, holiday weekends, and weekdays) that reflected the number of recreationists visiting Lake McConaughy. We defined weekends as Saturday and Sundays, holiday weekends as U.S. federal holidays (Memorial Day and Fourth of July) including the nearest weekend, and weekdays as Monday through Friday. The majority of weekend recreationists arrived at the lake in the late afternoon on Friday and left in the late afternoon on Sunday. We conducted our observations with the starting time moving between morning, midday, afternoon, and early evening to ensure that we sampled across the entire time period we expected the majority of ploverrecreationist interactions to take place $(0700 \mathrm{~h}$ to $1900 \mathrm{~h}$ local time; MDT),

Our observations took place on the beaches accessible to us and had a history of Piping Plover nesting; the study area extended from the waterline up to the line of permanent vegetation surrounding the lake. We recorded the location of all plover nests we observed, this included nests with and without protection by small exclosures. A small number of nests $(<5)$ located within the large 16 ha exclusion zones were not included in our study because recreation did not occur in close proximity to them. Observations were conducted at nests in an ordered rotation until they failed, e.g., succumbed to predation, or the eggs hatched.

\section{Response to stimuli}

In 2013 and 2014, we observed Piping Plover nests for one-hour units of time (plover observation hours). Observations were conducted from concealed positions located at least $100 \mathrm{~m}$ from nests, usually from the vegetated areas of the upper shoreline, to avoid disturbing the birds or to cause recreationists to modify their behavior. Using methods outlined by Weston and Elgar (2007) and Altmann (1974), we conducted Continuous Scan Sequence Sampling for each encounter. An encounter began when a stimulus moved within $100 \mathrm{~m}$ of an incubating plover on a nest. We defined a stimulus as any agent associated with human recreation capable of eliciting a response from a plover. When a stimulus was observed, we recorded (1) stimulus type, i.e., dog, human, human with dog, vehicle (licensed automobiles, pick-up trucks, recreational vehicles, golf carts, ATVs), (2) the duration, in seconds, the stimulus was present within $100 \mathrm{~m}$ of the nest, (3) whether the stimulus entered or stayed outside of the exclusion zone (compliant or noncompliant with the exclusion zone), and (4) whether the stimulus elicited a response by the plover attending the nest. Even though Piping Plover behavioral responses to disturbance are variable and may include feigning and distraction displays (Elliott-Smith and Haig 2004), the only response we observed was of birds standing and moving away from their nests. Thus, the response of the adult plover was binomial (1) no response (the plover remained at the nest and over the eggs) or (2) a response (the plover left the nest). If a response was observed, we estimated the distance between the nest and the stimulus at the time of the bird's response as the FID, in meters (Ydenberg and Dill 1986). If there was no response by the attending bird, we estimated the closest distance the stimulus approached to the nest. Distances were estimated with the aid of a laser rangefinder (Prostaff 3, Nikon, Melville, NY, USA). If we observed a response by the attending bird, we measured the amount of time (duration), in seconds, the plover was absent from the nest and refer to this as return time (Weston et al. 2011).

\section{Analyses}

The distribution of the number of stimuli by stimulus class was not significantly different between years $\left(\chi^{2}=1.02\right.$, $\mathrm{df}=2, p=$ 0.31 ). Therefore, we pooled our 2013 and 2014 data. We used oneway analysis of variance (ANOVA) to determine whether mean values for the number of stimuli encountered by day type (weekday, weekend, and holiday) and return times among stimuli were different. We used logistic regression in a generalized linear mixed model (GLMM; Zuur et al. 2007, Hilbe 2009) to identify the variables important in eliciting responses $(1=$ bird left the nest, $0=$ bird remained over the nest) by Piping Plovers attending their nests. We used logistic regression because only a subset of encounters resulted in flight initiation (response). Fixed variables included in the models were Julian day (1 January =1), hour of day (0700 to 1900 CDT), day type (weekend, holiday weekend, or weekday), exclosure size (16 x $16 \mathrm{~m}, 31 \times 31 \mathrm{~m}$, or none), stimulus class (dog, human, vehicle, human with dog), stimulus duration, and stimulus distance. Nest was the random effects variable in the analysis because individual nests were sampled more than once and at regular intervals across the incubation period.

For the logistic regression analyses, we used Akaike's Information Criterion (AICc) and model weights $\left(w_{i}\right)$ to select the model(s) that best fit the data (Burnham and Anderson 2002). We used $z-$ statistics to determine whether the maximum likelihood parameter estimates for the best-fitting model differed from zero. Models with the lowest AIC $c$ value were considered the best fitting and had the most support from the data; models within $\triangle \mathrm{AIC} \leq$ 2 were considered to have significant support from the data. Unless otherwise noted, means are presented $\pm 1 \mathrm{SE}$ and significance is set at alpha $=0.05$. All statistical analyses were performed in Program R 3.1.3 (R Development Core Team 2014).

\section{RESULTS}

We conducted 148 plover observation hours in 2013 and 73 plover observation hours in 2014. In 2013, 83 plover observation hours were completed during weekdays, 48 during weekends, and 17 during holidays. In 2014, 27 plover observation hours were completed during weekdays, 29 weekends and 17 during holidays. 
Table 1. Summary of Piping Plover (Charadrius melodus) encounters with stimuli showing overall number, stimuli per hour, number, and percent of encounters eliciting a response, distance of response and nearest approach, stimulus encounter duration, and return times. Piping Plovers responded more frequently and at greater distances when dogs were present. Return times were greatest for dogs and human with dog.

\begin{tabular}{|c|c|c|c|c|c|}
\hline & All natural stimuli & Dogs & Humans & Human w/dog & Vehicle \\
\hline Number (n) & 706 & 8 & 97 & 23 & 578 \\
\hline Stimuli per hour & 3.2 & $<0.1$ & 0.4 & 0.1 & 2.6 \\
\hline \# of encounters eliciting a response & 90 & 6 & 34 & 16 & 34 \\
\hline$\%$ of encounters eliciting a response & 12.7 & 75.0 & 35.0 & 70.0 & 5.9 \\
\hline Stimulus encounter duration (s) & $103 \pm 14$ & $298 \pm 162$ & $390 \pm 75$ & $205 \pm 56$ & $47 \pm 11$ \\
\hline Return time(s) & $161 \pm 17$ & $292 \pm 134$ & $158 \pm 24$ & $240 \pm 48$ & $108 \pm 20$ \\
\hline
\end{tabular}

Erratum: In the original publication of Table 1 incorrect figures were used for "All natural stimuli". The values were corrected on 28 March 2016.

We recorded 448 stimuli in 2013 and 258 stimuli in 2014 (Table 1). The number of stimuli encountered during plover observation hours was variable, ranging from 0 to 33 (mean $=3.20 \pm 0.28$ ). More stimuli were observed on holidays $(6.03 \pm 1.18)$ and weekends $(4.38 \pm 0.46)$ than on weekdays $(1.47 \pm 0.16)$. ANOVA for the number of encounters per plover observation hour showed that the effect of day type was significant $\left(F_{2,218}=25.13, P<\right.$ 0.001). Post hoc analyses using Tukey's HSD showed pairwise comparison between weekday and weekend $(P<0.001)$ and weekday and holiday $(P<0.001)$ were different.

Out of the 706 total natural stimuli, $1.0 \%(n=8)$ were dogs, $13.7 \%$ ( $n=97)$ were humans, $3.3 \%(n=23)$ were human with dogs, and $81.9 \%(n=578)$ were vehicles (Table 1). Personnel from CNPPID responsible for implementing the management plan were responsible for six of the 97 human stimuli. Only two instances of exclosure noncompliance, both involving dogs entering an exclusion zone, were observed. Attending Piping Plovers left the nest most frequently in response to dogs $(75.0 \%)$, human with dogs $(70.0 \%)$, humans $(35.0 \%)$, and vehicles $(5.9 \%)$. Return times (s) were greatest for dogs $(298 \pm 134)$ and humans with $\operatorname{dog}(240$ $\pm 48)$ compared to humans $(158 \pm 24)$ and vehicle $(108 \pm 20)$. ANOVA for return time showed that the effect of stimulus class was significant $\left(F_{3,86}=3.97, P=0.01\right)$. Post hoc analyses using Tukey's HSD showed only pairwise comparison between vehicle and human with dog was different $(P=0.03)$.

Our model selection procedure for the logistic regression analysis showed a model that included stimulus, Julian day, distance, and hour had the lowest AIC $c$ value (366.08; Table 2). Models with these same variables and which added day type or exclosure size had similar AICc values (369.31 and 369.75; Table 2), but the additional variable did not make the models competitive (Arnold 2010). Piping Plovers were less likely to respond when (1) the stimulus was vehicle or human compared to dog or human with $\operatorname{dog}$, (2) the stimulus was further from the nest, and (3) occurred earlier during the day and in the incubation period (Table 3, Fig. 2). Our model selection procedure showed exclosure size, stimulus duration and day type were not important variables associated with Piping Plover response. The proportion of the variance explained by individual nests was estimated at 0.33 , indicating individual bird's responses to stimuli are variable.
Fig. 2. Predicted mean probability and $95 \%$ confidence intervals (shading) of a Piping Plover (Charadrius melodus) nest absence by distance in response to four classes of naturally occurring human-related stimuli by hour of day at 0700 (solid line), 1300 (dashed line), and 1900 (dotted line) at the beginning (top row; Julian day 140), middle (middle row, Julian day 168), and end (lower row, Julian day 195) of the nesting season. Darker areas of shading show areas where $95 \%$ confidence intervals overlap. The probability of flight initiation decreased over the course of the incubation period for all stimuli, but increased slightly over the course of a day. Higher probability of flight initiation is predicted for dog and human with dog compared to human and vehicle across the incubation period.

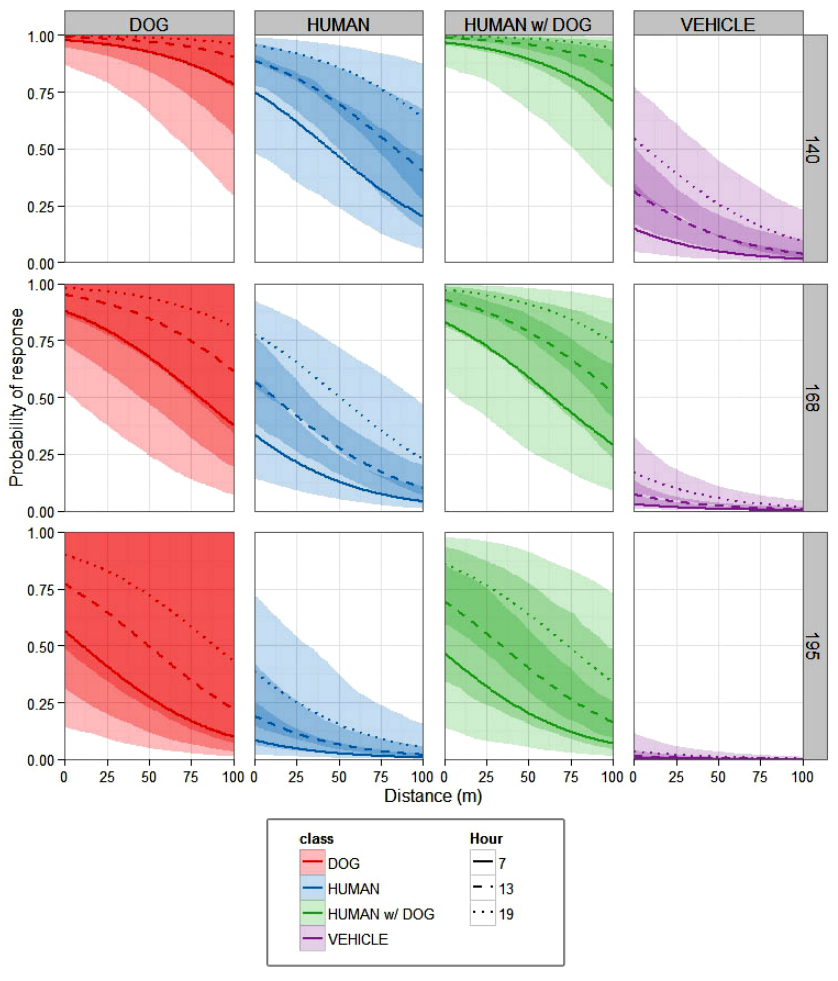


Table 2. Model selection summary of Piping Plover (Charadrius melodus) response to natural stimuli observed during the 2013 and 2014 nesting season. Results for all models with $w_{i} \geq 0.01$ are listed.

\begin{tabular}{|c|c|c|c|c|c|}
\hline Model & Log likelihood & $\mathrm{K}$ & $\mathrm{AIC} c$ & $\Delta \mathrm{AIC} c$ & $w_{i}$ \\
\hline Stimulus + Julian + distance + hour & -174.94 & 8 & 366.08 & - & 0.62 \\
\hline Stimulus + Julian + distance + exclosure + hour & -173.46 & 11 & 369.31 & 3.23 & 0.12 \\
\hline Stimulus + Julian + distance + day type + hour & -174.72 & 10 & 369.75 & 3.67 & 0.10 \\
\hline Stimulus + Julian + distance + exclosure + hour + duration & -173.25 & 12 & 370.95 & 4.87 & 0.05 \\
\hline Stimulus + Julian + distance + day type + hour + duration & -174.58 & 11 & 371.54 & 5.46 & 0.04 \\
\hline Stimulus + Julian + distance & -178.94 & 7 & 372.04 & 5.96 & 0.03 \\
\hline Stimulus + Julian + distance + day type + exclosure + hour & -173.12 & 13 & 372.76 & 6.68 & 0.02 \\
\hline Stimulus + Julian + distance + day type + duration & -172.91 & 14 & 374.42 & 8.34 & 0.01 \\
\hline
\end{tabular}

The predicted probability of a response at a consistent distance decreased over the nesting season, but increased slightly over the course of a day (Table 2, Fig. 2). The probability of a response over the nesting season decreased most for vehicle and human stimuli compared to dog and human with dogs (Table 2, Fig. 2). Piping Plovers were most likely to respond, and respond at a greater distance, when the stimulus included a dog (Table 2, Fig. 2).

Table 3. Estimates of maximum-likelihood parameters and significant deviation from 0 for the top model best describing response $(1=$ Piping Plover [Charadrius melodus] responded, $0=$ Piping Plover did not respond) to natural stimuli using logistic regression. Categorical variables for stimuli are relative to the parameter estimate for $\mathrm{dog}$.

\begin{tabular}{lccc}
\hline \hline Parameter & Estimate $\pm \mathrm{SE}$ & $z$-value & $p>z$ \\
\hline Stimuli (human) & $-2.66 \pm 1.22$ & -2.51 & 0.01 \\
Stimuli (vehicle) & $-5.50 \pm 1.09$ & -5.07 & $<0.001$ \\
Distance & $-0.02 \pm 0.01$ & -3.52 & $<0.001$ \\
Julian day & $-0.90 \pm 0.20$ & -4.54 & $<0.001$ \\
Hour & $0.16 \pm 0.06$ & 2.79 & $<0.01$ \\
\hline
\end{tabular}

\section{DISCUSSION}

Piping Plovers are now regularly nesting in anthropogenic habitats - areas impacted by human activities, e.g., recreation, aggregate mining, and residences. Human disturbance can cause behavioral changes in nesting plovers that lead to negative consequences, such as reduced nesting success, e.g., low egg hatching rate, or nest abandonment. Successful management of Piping Plovers (and humans) and implementation of the ESA in these areas must include efforts to avoid, or at least minimize, these negative consequences that may constitute instances of take under the ESA. The concept of FIDs has been used in developing the dimensions of human exclusion zones, but relationships between human disturbance, plover behavior, and negative effects on reproduction are not available. This has resulted in inconsistent implementation of protective exclusion zones, lack of clarity regarding the purpose of exclusion zones, and difficulties in defining what constitutes harassment (take) of Piping Plovers under the ESA.
In our study, incubating Piping Plovers responded differently to different types of stimuli. Plovers at nests responded the least (were more tolerant of) to vehicles, which were the most frequently experienced stimuli in our study. This result agrees with those of other studies (e.g., McLeod et al. 2013), which showed birds were more tolerant of vehicles compared to other stimuli, such as pedestrians. Piping Plovers were most likely to leave their nest in response to the presence of $\operatorname{dog}(\mathrm{s})$, even when the dogs were leashed and restrained by humans. Clearly, plovers perceive different levels of threat with different stimuli types and dogs represent a greater threat. These results indicate exclusion zone size should be developed with respect to the types of human activities present in Piping Plover nesting areas. For example, smaller exclusion zones may be effective in nesting areas where only vehicles are likely to be encountered and dogs are absent.

Piping Plovers appear able to habituate to human disturbance because they responded less vigorously to disturbance as the incubation period progressed. The birds responded to stimuli at the greatest distances early in incubation and at the smallest distances late in incubation. Interestingly, the birds became slightly more responsive to stimuli over the course of a day, suggesting there is a cumulative effect of stimuli experienced by the bird, but that value resets every morning. We are unable to exclude the possibility that the birds' investment in the nest (parental investment; Trivers 1974, Lima and Bednekoff 1999, Rodriguez-Prieto et al. 2009) influenced their response behavior because the probability of a nest's success increases over time (de Jong et al. 2013).

We observed many instances in which incubation was interrupted because of human disturbance, but determining whether the disturbance negatively affected nest survival was beyond the scope of our study. The majority of the return times we observed were brief (less than three minutes) and apparent nest success at Lake McConaughy was $66.2 \%(\mathrm{n}=86)$ and $68.5 \%(\mathrm{n}=89)$ in 2013 and 2014, respectively (Peyton and Wilson 2013, 2014), which is relatively high compared to other reported values (Catlin et al. $2011,2015)$. Taken together this suggests that relatively brief nest absences by themselves are unlikely to result in negative consequences to the birds' nesting efforts. However, during our study Piping Plovers encountered on average less than four stimuli per hour and many of those did not approach the boundary of the exclusion zones or remain in the area for extended periods. Nesting areas or temporal periods, e.g., weekend or holidays, with 
more intensive recreation and higher stimulus encounter rates, particularly associated with dogs, for longer periods of time are more likely to experience nest loss or abandonment.

An important limitation of our study is that we only evaluated the consequences of human disturbance during the incubation period. Piping Plover chicks are precocial and mobile shortly after they hatch (Elliott-Smith and Haig 2004). They require access to habitat of sufficient size and quality that allows them to develop and survive to fledging (Loegering and Fraser 1995). It is quite likely that adult and chick behavioral responses to human disturbance and associated negative effects are different during the brood rearing portion of the breeding cycle (Flemming et al. 1988, Weston and Elgar 2005, Weston et al. 2011). Buffer distances for incubating birds may be insufficient for brood-rearing birds. Collectively, these results point to the need for additional studies focused on FIDs in different settings to evaluate the full range of responses that might be experienced by Piping Plovers.

\section{CONCLUSIONS}

Managing human activities in areas used by nesting Piping Plovers has become a central challenge for conservation practitioners as human use intensifies in areas where plovers nest and rear their young. Human exclusion zones are a common practice used to protect and avoid take of Piping Plovers. Our results show Piping Plovers respond differently to different types of stimuli associated with human activity, which indicates exclusion zone sizes could be customized for the types of activity occurring in areas where Piping Plovers nest. The current available recommendation of exclusion zones with buffer distances of 50 $m$ by USFWS (1994) appears sufficient to prevent Piping Plovers from leaving their nests for a high proportion of encounters with humans and vehicles, but not sufficient to avoid most nest absences caused by encounters with dogs. Because Piping Plovers appear capable of becoming habituated to stimuli with repeated exposure, decreasing the size of exclusion zones over the course of a nesting season may be as effective as using one size throughout the entire season. However, recreational activity in other nesting areas may be different than what we observed during our study and the intensity of recreation should be considered in formulating the size of exclusion zones. Additional research is needed regarding (1) linkages between human disturbance, behavioral responses by plovers, and negative effects, e.g., nest success, on plovers and (2) plover responses to human disturbance during the brood-rearing and overwintering periods. The regulatory agencies charged with implementing legal protection of plovers should identify their desired outcomes for the implementation of human exclusion zones, e.g., avoiding all nest absences due to disturbance or nest abandonment. It is critical for managers to have access to improved guidance for the implementation of exclusion zones in anthropogenic landscapes.

Responses to this article can be read online at: http://www.ace-eco.org/issues/responses.php/826

\section{Acknowledgments:}

Principal funding for this project was provided by the Nebraska State Wildlife Grants program with additional support provided by the Nebraska Environmental Trust, Nebraska Game and Parks Commission, Nebraska Wildlife Conservation Fund, and University of Nebraska School of Natural Resources. We especially thank Jamie Briske, Lindsay Brown, Peyton Burt, Chris Chizinski, Edward Raynor, Zach Schafer, Erica Stuber, and Jessica Tramp for their assistance on this project. We also thank Ryan Norris and Daniel Catlin for comments that improved the manuscript. We thank all the individuals and agencies that assisted us with this project including: Cedar Point Biological Station, Central Nebraska Public Power and Irrigation District, Nebraska Game and Parks Commission Parks and Wildlife Divisions, U.S. Fish and Wildlife Service, Karie Decker, Shaun Dunn, Leslie Hershberger, Colby Johnson, Teresa Lombard, Kirk Nelson, Mark Peyton, Rachel Simpson, Kristal Stoner, Scott Taylor, and Gabe Wilson.

\section{LITERATURE CITED}

Altmann, J. 1974. Observational study of behavior: sampling methods. Behaviour 49:227-267. http://dx.doi.org/10.1163/156853974X00534

Arnold, T. W. 2010. Uninformative parameters and model selection using Akaike's Information Criterion. Journal of Wildlife Management 74:1175-1178. http://dx.doi.org/10.2193/2009-367

Baudains, T. P., and P. Lloyd. 2007. Habituation and habitat changes can moderate the impacts of human disturbance on shorebird breeding performance. Animal Conservation 10:400-407. http://dx.doi.org/10.1111/j.1469-1795.2007.00126.x

Blumstein, D. T. 2003. Flight-initiation distance in birds is dependent on intruder starting distance. Journal of Wildlife Management 67:852-857. http://dx.doi.org/10.2307/3802692

Blumstein, D. T., L. L. Anthony, R. Harcourt, and G. Ross. 2003. Testing a key assumption of wildlife buffer zones: Is flight initiation distance a species-specific trait? Biological Conservation 110:97-100. http://dx.doi.org/10.1016/s0006-3207(02)00180-5

Boyle, S. A., and F. B. Samson. 1985. Effects of nonconsumptive recreation on wildlife: a review. Wildlife Society Bulletin 13:110-116.

Brown, M. B., M. E. Burbach, J. Dinan, R. J. Held, R. J. Johnson, J. G. Jorgensen, J. Lackey, J. F. Marcus, G. S. Matkin, and C. M. Thody. 2010. Nebraska's tern and plover conservation partnership-a model for sustainable conservation of threatened and endangered species. Wader Study Group Bulletin 118:22-25.

Burger, J. 1991. Foraging behavior and the effect of human disturbance on the Piping Plover (Charadrius melodus). Journal of Coastal Research 7:39-52.

Burger, J. 1994. The effect of human disturbance on foraging behavior and habitat use in Piping Plover (Charadrius melodus). Estuaries 17:695-701. http://dx.doi.org/10.2307/1352418

Burger, J., and M. Gochfeld. 1983. Behavioural responses to human intruders of Herring Gulls (Larus argentatus) and Great Black-backed Gulls (L. marinus) with varying exposure to human disturbance. Behavioural Processes 8:327-344. http://dx.doi. org/10.1016/0376-6357(83)90022-0

Burger, J., and M. Gochfeld. 1991. Human distance and birds: tolerance and response distances of resident and migrant species 
in India. Environmental Conservation 18:158-165. http://dx.doi. org/10.1017/S0376892900021743

Burger, J., M. Gochfeld, C. D. Jenkins, and F. Lesser. 2010. Effect of approaching boats on nesting black skimmers: using response distances to establish protective buffer zones. Journal of Wildlife Management 74:102-108. http://dx.doi.org/10.2193/2008-576

Burnham, K. P., and D. R. Anderson. 2002. Model selection and multimodel inference: a practical information-theoretic approach. Springer-Verlag, New York, New York, USA. http://dx.doi. org/10.1007/b97636

Carney, K. M., and W. J. Sydeman. 1999. A review of human disturbance effects on nesting colonial waterbirds. Waterbirds 22:68-79. http://dx.doi.org/10.2307/1521995

Catlin, D. H. 2009. Population dynamics of Piping Plovers (Charadrius melodus) on the Missouri River. Dissertation, Virginia Polytechnic Institute and State University, Blacksburg, Virginia, USA.

Catlin, D. H., J. D. Fraser, and J. H. Felio. 2015. Demographic responses of Piping Plovers to habitat creation on the Missouri river. Wildlife Monographs 192:1-42. http://dx.doi.org/10.1002/ wmon.1016

Catlin, D. H., J. D. Fraser, J. H. Felio, and J. B. Cohen. 2011. Piping Plover habitat selection and nest success on natural, managed, and engineered sandbars. Journal of Wildlife Management 75:305-310. http://dx.doi.org/10.1002/jwmg.46

Central Nebraska Public Power and Irrigation District (CNPPID). 2002. Land and shoreline management plan for the Kingsley Dam Project: Federal Energy Regulatory Agency License No. 1417. Central Nebraska Public Power and Irrigation District, Holdrege, Nebraska, USA.

Clark, C. W., and R. C. Ydenberg. 1990. The risks of parenthood. I. General theory and applications. Evolutionary Ecology 4:21-34. http://dx.doi.org/10.1007/BF02270712

Crooks, K. R., A. V. Suarez, and D. T. Bolger. 2004. Avian assemblages along a gradient of urbanization in a highly fragmented landscape. Biological Conservation 115:451-462. http://dx.doi.org/10.1016/S0006-3207(03)00162-9

Deblinger, R. D., J. J. Vaske, and D. W. Rimmer. 1992. An evaluation of different predator exclosures used to protect Atlantic Coast Piping Plover nests. Wildlife Society Bulletin 20:274-279.

de Jong, A., C. Magnhagen, and C. G. Thulin. 2013. Variable flight initiation distance in incubating Eurasian curlew. Behavioral Ecology and Sociobiology 67:1089-1096. http://dx.doi.org/10.1007/ s00265-013-1533-6

Eason, P. K., P. T. Sherman, O. Rankin, and B. Coleman. 2006. Factors affecting flight initiation distance in American Robins. Journal of Wildlife Management 70:1796-1800. http://dx.doi. org/10.2193/0022-541X(2006)70[1796:FAFIDI]2.0.CO;2

Elliott-Smith, E., M. Bidwell, A. E. Holland, and S. M. Haig. 2015. Data from the 2011 international Piping Plover census. U.S. Geological Survey Data Series. Reston, Virginia, USA. http://dx. doi.org/10.3133/ds922
Elliott-Smith, E., and S. M. Haig. 2004. Piping Plover (Charadrius melodus). In A. Poole, editor. The birds of North America online. Cornell Lab of Ornithology, Ithaca, New York, USA. [online] URL: http://bna.birds.cornell.edu/bna/species/002

Elliott-Smith, E., S. M. Haig, and B. M. Powers. 2009. Data from the 2006 international Piping Plover census. U.S. Geological Survey Data Series. Reston, Virginia, USA.

Fernández-Juricic, E., M. P. Venier, D. Renison, and D. T. Blumstein. 2005. Sensitivity of wildlife to spatial patterns of recreationist behavior: a critical assessment of minimum approaching distances and buffer areas for grassland birds. Biological Conservation 125:225-235. http://dx.doi.org/10.1016/j. biocon.2005.03.020

Flemming, S. P., R. D. Chiasson, P. C. Smith, P. J. Austin-Smith, and R. P. Bancroft. 1988. Piping Plover status in Nova Scotia related to its reproductive and behavioral responses to human disturbance. Journal of Field Ornithology 59:321-330.

Gill, J. A., K. Norris, and W. J. Sutherland. 2001. Why behavioural responses may not reflect the population consequences of human disturbance. Biological Conservation 97:265-268. http://dx.doi. org/10.1016/S0006-3207(00)00002-1

Hilbe, J. M. 2009. Logistic regression models. Chapman and Hall, London, UK.

Ikuta, L. A., and D. T. Blumstein. 2003. Do fences protect birds from human disturbance? Biological Conservation 112:447-452. http://dx.doi.org/10.1016/S0006-3207(02)00324-5

Jorgensen, J. G., and M. B. Brown. 2014. Piping Plovers Charadrius melodus and dogs: compliance with and attitudes toward a leash law on public beaches at Lake McConaughy, Nebraska, USA. Wader Study Group Bulletin 121:7-12.

Jorgensen, J. G., and M. B. Brown. 2015. Evaluating recreationists' awareness and attitudes toward Piping Plovers (Charadrius melodus) at Lake McConaughy, Nebraska, USA Human Dimensions of Wildlife 20:367-380. http://dx.doi. org/10.1080/10871209.2015.1020579

Lafferty, K. D., D. Goodman, and C. P. Sandoval. 2006. Restoration of breeding by Snowy Plovers following protection from disturbance. Biodiversity \& Conservation 15:2217-2230. http://dx.doi.org/10.1007/s10531-004-7180-5

Liao, J., D. T. Blumstein, S. Libby, and C. Geist. 2005. Does intruder group size and orientation affect flight initiation distance in birds? Animal Biodiversity and Conservation 28:69-73.

Lima, S. L., and P. A. Bednekoff. 1999. Temporal variation in danger drives antipredator behavior: the predation risk allocation hypothesis. American Naturalist 153:649-659. http://dx.doi. org/10.1086/303202

Loegering, J. P., and J. D. Fraser. 1995. Factors affecting Piping Plover chick survival in different brood-rearing habitats. Journal of Wildife Management 59:646-655. http://dx.doi.org/10.2307/3801940

Lord, A., J. R. Waas, J. Innes, and M. J. Whittingham. 2001. Effects of human approaches to nests of northern New Zealand Dotterels. Biological Conservation 98:233-240. http://dx.doi. org/10.1016/S0006-3207(00)00158-0 
McLeod, E. M., P. J. Guay, A. J. Taysom, R. W. Robinson, and M. A. Weston. 2013. Buses, cars, bicycles and walkers: the influence of the type of human transport on the flight responses of waterbirds. PLoS ONE 8(12):e82008. http://dx.doi. org/10.1371/journal.pone.0082008

Melvin, S. M., A. Hecht, and C. R. Griffin. 1994. Piping Plover mortalities caused by off-road vehicles on Atlantic coast beaches. Wildlife Society Bulletin 22:409-414.

Nisbet, I. C. 2000. Disturbance, habituation, and management of waterbird colonies. Waterbirds 23:312-332.

Peyton, M. M., and G. T. Wilson. 2013. Least Tern and Piping Plover nest monitoring. Central Nebraska Public Power and Irrigation District, Holdrege, Nebraska, USA.

Peyton, M. M., and G. T. Wilson. 2014. Least Tern and Piping Plover nest monitoring. Central Nebraska Public Power and Irrigation District, Holdrege, Nebraska, USA.

R Development Core Team. 2014. R: A language and environment for statistical computing, v. 3.1.3. R Foundation for Statistical Computing, Vienna, Austria. [online] URL: http://www.Rproject.org/

Rodgers Jr., J. A., and H. T. Smith. 1995. Set-back distances to protect nesting bird colonies from human disturbance in Florida. Conservation Biology 9:89-99. http://dx.doi.org/10.1046/ j.1523-1739.1995.09010089.x

Rodriguez-Prieto, I., E. Fernández-Juricic, J. Martín, and Y. Regis. 2009. Antipredator behavior in blackbirds: habituation complements risk allocation. Behavioral Ecology 20:371-377. http://dx.doi.org/10.1093/beheco/arn151

Stillman, R. A., and J. D. Goss-Custard. 2002. Seasonal changes in the response of oystercatchers Haematopus ostralegus to human disturbance. Journal of Avian Biology 33:358-365. http:// dx.doi.org/10.1034/j.1600-048X.2002.02925.X

Trivers, R. L. 1974. Parent-offspring conflict. American Zoologist 14:249-264. http://dx.doi.org/10.1093/icb/14.1.249

U.S. Fish and Wildlife Service (USFWS). 1988. Great Lakes and northern Great Plains Piping Plover recovery plan. U.S. Fish and Wildlife Service, Twin Cities, Minnesota, USA.

U.S. Fish and Wildlife Service (USFWS). 1994. Guidelines for managing recreational activities in Piping Plover breeding habitat on the U.S. Atlantic Coast to avoid take under Section 9 of the Endangered Species Act. U.S. Fish and Wildlife Service Northeast Region, Hadley, Massachusetts, USA.

U.S. Fish and Wildlife Service (USFWS). 1996. Piping plover (Charadrius melodus) Atlantic Coast population revised recovery plan. U.S. Fish and Wildlife Service, Hadley, Massachusetts, USA.
U.S. Fish and Wildlife Service (USFWS). 2003. Recovery plan for the Great Lakes Piping Plover (Charadrius melodus). U.S. Fish and Wildlife Service, Fort Snelling, Minnesota. USA.

Weston, M. A., G. C. Ehmke, and G. S. Macguire. 2011. Nest return times in response to static versus mobile human disturbance. Journal of Wildlife Management 75:252-255. http:// dx.doi.org/10.1002/jwmg.7

Weston, M. A., and M. A. Elgar. 2005. Disturbance to broodrearing Hooded Plover Thinornis rubricollis: responses and consequences. Bird Conservation International 15:193-209. http:// dx.doi.org/10.1017/S0959270905000158

Weston, M. A., and M. A. Elgar. 2007. Responses of incubating Hooded Plovers (Thinornis rubricollis) to disturbance. Journal of Coastal Research 23:569-576. http://dx.doi.org/10.2112/04-0151.1

Yasué, M., and P. Dearden. 2006. The effects of heat stress, predation risk and parental investment on Malaysian plover nest return times following a human disturbance. Biological Conservation 132:472-480. http://dx.doi.org/10.1016/j.biocon.2006.04.038

Ydenberg, R. C., and L. M. Dill. 1986. The economics of fleeing from predators. Advances in the Study of Behavior 16:229-249. http://dx.doi.org/10.1016/S0065-3454(08)60192-8

Zuur, A. F., E. N. Ieno, and G. M. Smith. 2007. Analysing ecological data. Springer Science \& Business Media, New York, New York, USA. http://dx.doi.org/10.1007/978-0-387-45972-1
Editor-in-Chief: Ryan Norris Subject Editor: Erica Nol
Sponsored by the Society of Canadian Ornithologists and Bird Studies Canada Parrainée par la Société des ornithologistes du Canada et Études d'oiseaux Canada

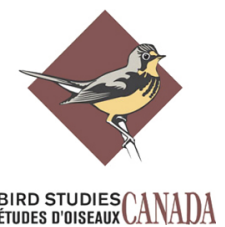

